\title{
Front Matter: Volume 11016
}

, "Front Matter: Volume 11016," Proc. SPIE 11016, Sensing for Agriculture and Food Quality and Safety XI, 1101601 (1 July 2019); doi: 10.1117/12.2536299

SPIE Event: SPIE Defense + Commercial Sensing, 2019, Baltimore, MD, United SPIE. States 


\section{PROCEEDINGS OF SPIE}

\section{Sensing for Agriculture and Food Quality and Safety XI}

Moon S. Kim

Bryan A. Chin

Byoung-Kwan Cho

Editors

16-17 April 2019

Baltimore, Maryland, United States

Sponsored and Published by

SPIE 
The papers in this volume were part of the technical conference cited on the cover and title page. Papers were selected and subject to review by the editors and conference program committee. Some conference presentations may not be available for publication. Additional papers and presentation recordings may be available online in the SPIE Digital Library at SPIEDigitalLibrary.org.

The papers reflect the work and thoughts of the authors and are published herein as submitted. The publisher is not responsible for the validity of the information or for any outcomes resulting from reliance thereon.

Please use the following format to cite material from these proceedings:

Author(s), "Title of Paper," in Sensing for Agriculture and Food Quality and Safety XI, edited by Moon S. Kim, Bryan A. Chin, Byoung-Kwan Cho, Proceedings of SPIE Vol. 11016 (SPIE, Bellingham, WA, 2019) Seven-digit Article CID Number.

ISSN: 0277-786X

ISSN: 1996-756X (electronic)

ISBN: 9781510626973

ISBN: 9781510626980 (electronic)

Published by

SPIE

P.O. Box 10, Bellingham, Washington 98227-0010 USA

Telephone +1 3606763290 (Pacific Time) · Fax +1 3606471445

SPIE.org

Copyright (C) 2019, Society of Photo-Optical Instrumentation Engineers.

Copying of material in this book for internal or personal use, or for the internal or personal use of specific clients, beyond the fair use provisions granted by the U.S. Copyright Law is authorized by SPIE subject to payment of copying fees. The Transactional Reporting Service base fee for this volume is $\$ 18.00$ per article (or portion thereof), which should be paid directly to the Copyright Clearance Center (CCC), 222 Rosewood Drive, Danvers, MA 01923. Payment may also be made electronically through CCC Online at copyright.com. Other copying for republication, resale, advertising or promotion, or any form of systematic or multiple reproduction of any material in this book is prohibited except with permission in writing from the publisher. The CCC fee code is 0277$786 \mathrm{X} / 19 / \$ 18.00$.

Printed in the United States of America by Curran Associates, Inc., under license from SPIE.

Publication of record for individual papers is online in the SPIE Digital Library.

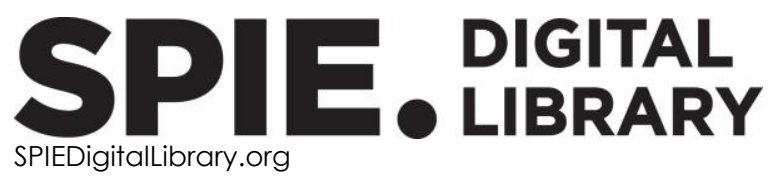

Paper Numbering: Proceedings of SPIE follow an e-First publication model. A unique citation identifier (CID) number is assigned to each article at the time of publication. Utilization of CIDs allows articles to be fully citable as soon as they are published online, and connects the same identifier to all online and print versions of the publication. SPIE uses a seven-digit CID article numbering system structured as follows:

- The first five digits correspond to the SPIE volume number.

- The last two digits indicate publication order within the volume using a Base 36 numbering system employing both numerals and letters. These two-number sets start with 00, 01, 02, 03, 04, 05, 06, 07, 08, 09, 0A, OB ... 0Z, followed by 10-1Z, 20-2Z, etc. The CID Number appears on each page of the manuscript. 


\title{
Contents
}

\author{
$\checkmark \quad$ Authors \\ vii Conference Committee
}

\section{SESSION 1 FOOD ADULTERANT AND TOXIN}

1101602 Authentication of turmeric powder using hyperspectral Raman system [1 1016-1]

1101603 Potential of near-infrared hyperspectral imaging in discriminating corn kernels infected with aflatoxigenic and non-aflatoxigenic Aspergillus flavus [1 1016-2]

\section{SESSION 2 MEAT QUALITY AND SAFETY}

1101607 Development and validation of a multi gas optical sensor for the meat industry [11016-6]

\section{SESSION $3 \quad$ PATHOGEN DETECTION}

1101608 Classification of Arcobacter species using variational autoencoders (Invited Paper) [11016-7]

$1101609 \quad$ Multiplexed detection of lanthanides using laser-induced breakdown spectroscopy: a survey of data analysis techniques [11016-8]

$11016 \mathrm{OB} \quad$ Rapid detection of pathogens using direct and surface enhanced Raman spectroscopy [11016-10]

SESSION 4 FOOD SAFETY AND QUALITY

$110160 \mathrm{C}$ Multivariate predictive models for the prediction of fatty acids in the EU high added-value "acorn lberian pig ham" using a miniature near-infrared spectroscopy instrument (Invited Paper) [11016-11]

11016 OE Portable bioluminescence detection for food safety: smartphone vs. silicon photomultiplier [11016-13]

11016 OF Selection of optimal bands for developing multispectral system for inspecting apples for defects [11016-14] 


\section{POSTER SESSION}

11016 OG Nondestructive rapid detection of benzoyl peroxide in flour based on Raman hyperspectral technique [11016-15]

1101600 Detection of produce residues on processing equipment surfaces using fluorescence imaging [11016-23] 


\section{Authors}

Numbers in the index correspond to the last two digits of the seven-digit citation identifier (CID) article numbering system used in Proceedings of SPIE. The first five digits reflect the volume number. Base 36 numbering is employed for the last two digits and indicates the order of articles within the volume. Numbers start with 00, 01, 02, 03, 04, 05, 06, 07, 08, 09, OA, OB...0Z, followed by 10-1Z, 20-2Z, etc.

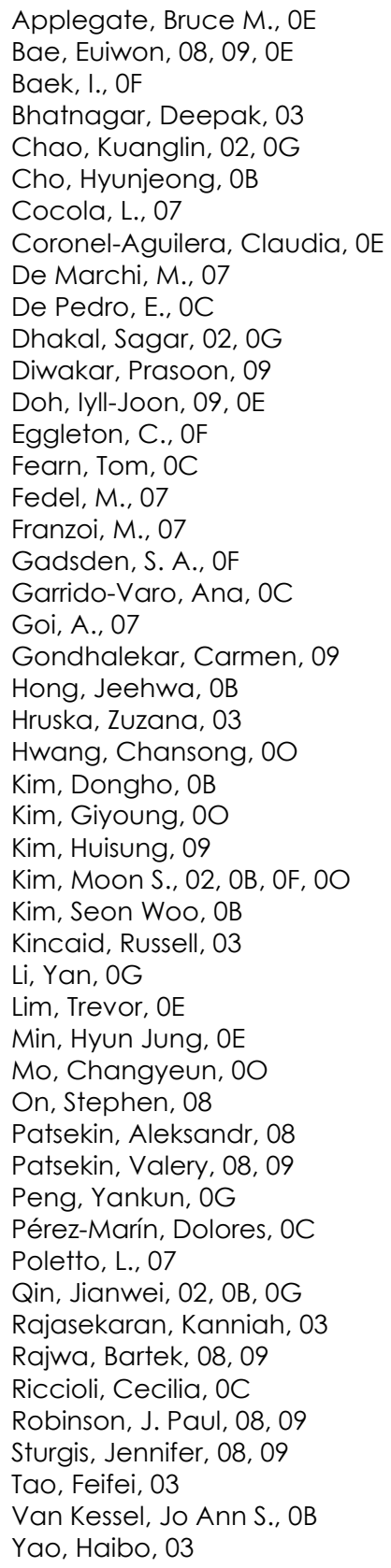


Proc. of SPIE Vol. 11016 1101601-6 Downloaded From: https://www.spiedigitallibrary.org/conference-proceedings-of-spie on 26 Apr 2023
Terms of Use: https://www.spiedigitallibrary.org/terms-of-use 


\section{Conference Committee}

Symposium Chairs

Jay Kumler, JENOPTIK Optical Systems, LLC (United States)

Ruth L. Moser, Air Force Research Laboratory (United States)

Symposium Co-chair

John Pellegrino, Electro-Optical Systems Laboratory, Georgia Institute of Technology (United States)

Conference Chairs

Moon S. Kim, USDA Agricultural Research Service (United States)

Bryan A. Chin, Auburn University (United States)

Byoung-Kwan Cho, Chungnam National University

(Korea, Republic of)

Conference Program Committee

Arun K. Bhunia, Center for Food Safety Engineering, Purdue University (United States)

Kuanglin Chao, USDA Agricultural Research Service (United States)

Stephen R. Delwiche, USDA Agricultural Research Service (United States)

Ana Garrido-Varo, Universidad de Córdoba (Spain)

Ki-Bok Kim, Korea Research Institute of Standards and Science (Korea, Republic of)

Naoshi Kondo, Kyoto University Graduate School of Agriculture (Japan)

Kurt C. Lawrence, USDA Agricultural Research Service (United States)

Changying (Charlie) Li, The University of Georgia (United States)

Renfu Lu, USDA Agricultural Research Service (United States)

Changyeun Mo, National Institute of Agricultural Sciences (Korea,

Republic of)

Bosoon Park, USDA Agricultural Research Service (United States)

Yankun Peng, China Agricultural University (China)

Dolores Pérez-Marín, Universidad de Córdoba (Spain)

Amrita Sahu, Altria Group, Inc. (United States)

Gang Yao, University of Missouri-Columbia (United States)

Haibo Yao, Mississippi State University (United States)

Yibin Ying, Zhejiang University (China)

Seung-Chul Yoon, USDA Agricultural Research Service (United States) 


\section{Session Chairs}

1 Food Adulterant and Toxin

Seung-Chul Yoon, Agricultural Research Service (United States)

2 Meat Quality and Safety

Jianwei Qin, Agricultural Research Service (United States)

3 Pathogen Detection

Byoung-Kwan Cho, Chungnam National University

(Korea, Republic of)

4 Food Safety and Quality

Songtao Du, Auburn University (United States) 